\title{
ETHNOMATHEMATICS EXPLORATION IN PANATARAN TEMPLE AND ITS IMPLEMENTATION IN LEARNING
}

\author{
Jayanti Munthahana $^{1^{*}}$, Mega Teguh Budiarto ${ }^{2}$ \\ ${ }^{1,2}$ Department of Mathematics Education, Faculty of Mathematics and Natural Science, Universitas Negeri \\ Surabaya, Indonesia
}

*Corresponding author: jayantimunthahana@mhs.unesa.ac.id

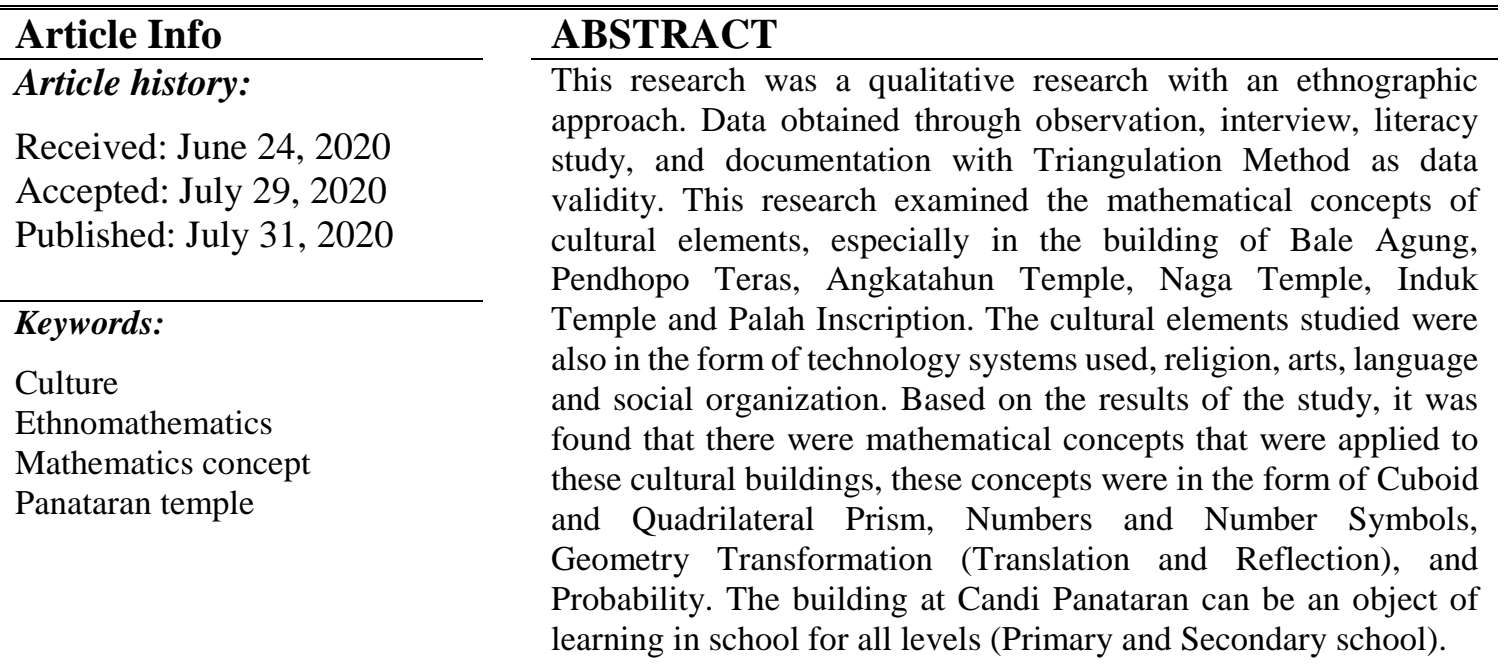

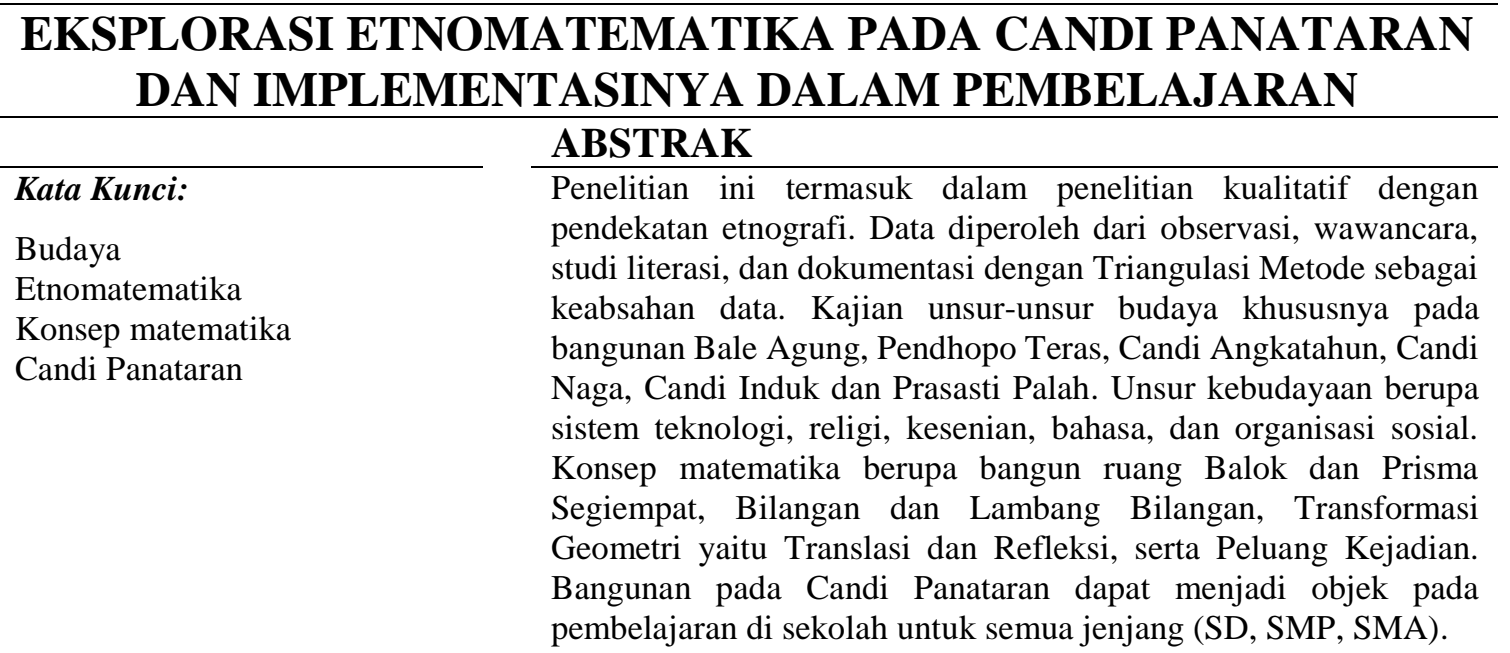

\section{INTRODUCTION}

Culture is a human activity that becomes a proud identity for individuals and society [1]-[5]. Based on Mallinowski's opinion, culture in the world has seven universal cultures, those are; (1) Language, is used by humans to interact with others. Indonesia has a variety of languages which are influenced by cultural diversity. (2) A technological system, not 
only in the form of machines, but also in the form of human works that can be used efficiently such as simple tools made of wood, metal, or stone. (3) Livelihood system, at the beginning of human life, humans met their needs by gathering natural products. As time goes by, people think about the sustainability of natural products that are not always available, so that a culture of farming or raising livestock to get food has emerged. (4) Social organization, each community group has customs and rules in social life and interaction. (5) The knowledge system, the knowledge possessed by the ancestors, has an effect on the development of knowledge in the present. For example, rural communities who live from farming will have an agricultural calendar system, planting corn cannot be done during the rainy season. (6) Religion, every culture has a belief system, such as belief in the supernatural things. (7) Art. Art can be said to be ideas, values, and regulations that are the result of human expression by involving the process of using the creative human imagination [6], [7]. The seven elements are universal and can identify social groups, ethnicities or countries using an ethnographic framework, so it can be said that all human activities can be classified into one of these elements.

Mathematics and culture are two things that are closely related [8]-[10]. Culture is important to be included as a topic in learning, because learning in school currently emphasizes the formation of positive characters that reflect the cultural values of the nation [3], [11], [12]. Furthermore, including culture in learning will make students motivated to recognize their culture and proud of the culture that becomes their identity. Culture-based mathematics, often called ethnomatematics, is an approach used to explain the role of mathematics in culture. Ethnomatematics can be described as a way, in which people from certain cultures use mathematical ideas and concepts in their culture [9], [10], [13], [14]. Objects in ethnomatematics are community activities, historical objects, and cultural products of a society that have mathematical concepts. The purpose of ethnomatematics is to understand the relationship between mathematics and culture, so that students' perceptions of mathematics become more precise, and learning mathematics becomes more meaningful because it is adjusted to the context of culture and social life. [3], [10], [14].

Ditasona's research used a cultural context in the form of a gorga which is an ornament of a traditional Batak house. From several gorga motifs it can be concluded that the motive has used the mathematical concept of geometric transformation in the form of reflection, rotation, translation, and dilation[10]. Gorga can be a cultural context that can be included in learning, so that it can be a method for students to study the topic of geometric transformation. Budiarto revealed that there is a cultural context in the form of Toraja carvings on the Tongkonan traditional house, ornaments on the Tanleyan Lajang Madura settlement, model houses in East Nusa Tenggara such as Ume Kbubu, ornaments on furniture at Kraton Pasuruan, pottery from the Sasak tribe of Banyumulek, West Lombok, paintings on the bark of the Asmat tribe, Tenun Ikat (weaving) form Sendang Duwur Lamongan, weaving from North Central Timor and Southwest Sumba, traditional houses in Manggarai and North Central Timor, non-standard sizes of fish farming communities on the north coast of Java (pantura), non-standard area units in the interior of East Java and patterns on woven bamboo in Banyuwagi district [4]. People with these cultures make carvings based on what they see and experience in their daily life. In these carvings, natural expressions are found as outlined in geometric shapes (circles, triangles, squares) and the concept of right angles. Non-standard units are used in fish farming communities and rice field farmers, such as rean, bata, and sejinah units. 
Panataran temple is one of the cultural products in Indonesia. The Panataran Temple Complex is the largest temple complex in East Java [15]-[17]. The temple courtyard is divided into three parts, and the Panataran temple complex is also divided into three terraces i.e. front porch, middle terrace and back porch [17]. The Penataran Temple complex has various buildings. Several buildings were taken as objects regarding the ethnomatematics of Candi Panataran, those are: Bale Agung, Pendhopo Teras, Angkatahun Temple, Naga temple, Induk Temple (Main Temple), and Palah Inscription. In each building there are functions and folk tales that contain a philosophy of life. For example, in the Pendhopo Teras building, there are three folk tales contained in the carvings, Sri Tanjung, Babhuksah Gagangaking, and Sang Setyawan. Sri Tanjung told about the wife's belief in her husband, Babhuksah Gagangaking told about a person's sincerity in worshiping, and Sang Setyawan told about a person in high position who was very obedient and not arrogant [15]-[17].

To raise the important cultural history and philosophy to be conveyed to students, we conducted an ethnomatematic study at Candi Panataran which aimed to describe the ethnomatematic form in Candi Panataran and found mathematical concepts in Candi Panataran so that it can be used as material for learning at school.

\section{METHOD}

This qualitative research with an ethnographic approach was conducted in 2020 . The data taken were in the form of mathematical concepts in the Panataran Temple building. Data obtained through observation, interviews, literacy studies, and documentation. The research instrument consists of two types of instruments, the main instrument and the supporting instrument. The main instrument was the researchers. Supporting instruments were in the form of interview guidelines and observation guidelines. The data analysis used the ethnographic approach proposed by Spradley, namely domain analysis, taxonomic analysis, component analysis, and discovery of cultural themes [18]. Researchers conducted direct data collection by conducting interviews with informants, interviews were conducted at the location of the Candi Panataran complex on Tuesday, March 17, 2020 at 09.46-12.00 am. Data validity was confirmed by Triangulation Method. Triangulation can be done by using more than one data collection technique to obtain the same data [19]. In this study, the validity of the data was obtained from interviews with informants and literature review, observation, and supported by documentation. Table 1 presents the informant data in this study.

Table 1. List of Research Informants

\begin{tabular}{clc}
\hline No & \multicolumn{1}{c}{ Informant } & Domicile \\
\hline 1 & Cultural practitioner & Blitar \\
2 & Archival officer at the Research and Cultural Heritage Center & Mojokerto \\
3 & Documentation Clerk at the Research and Cultural Heritage Center & Mojokerto \\
\hline
\end{tabular}

The informants were selected based on Spradley's criteria, namely full enculturation (informants know the culture well because they carry out cultural activities automatically and routinely from year to year), informants are directly involved in the cultural atmosphere so that informants provide detailed knowledge, informants know the cultural atmosphere what researchers do not know, informants have enough time, informants use their language in describing events and providing analysis and interpretation [18]. This research procedure is depicted in Figure 1. 


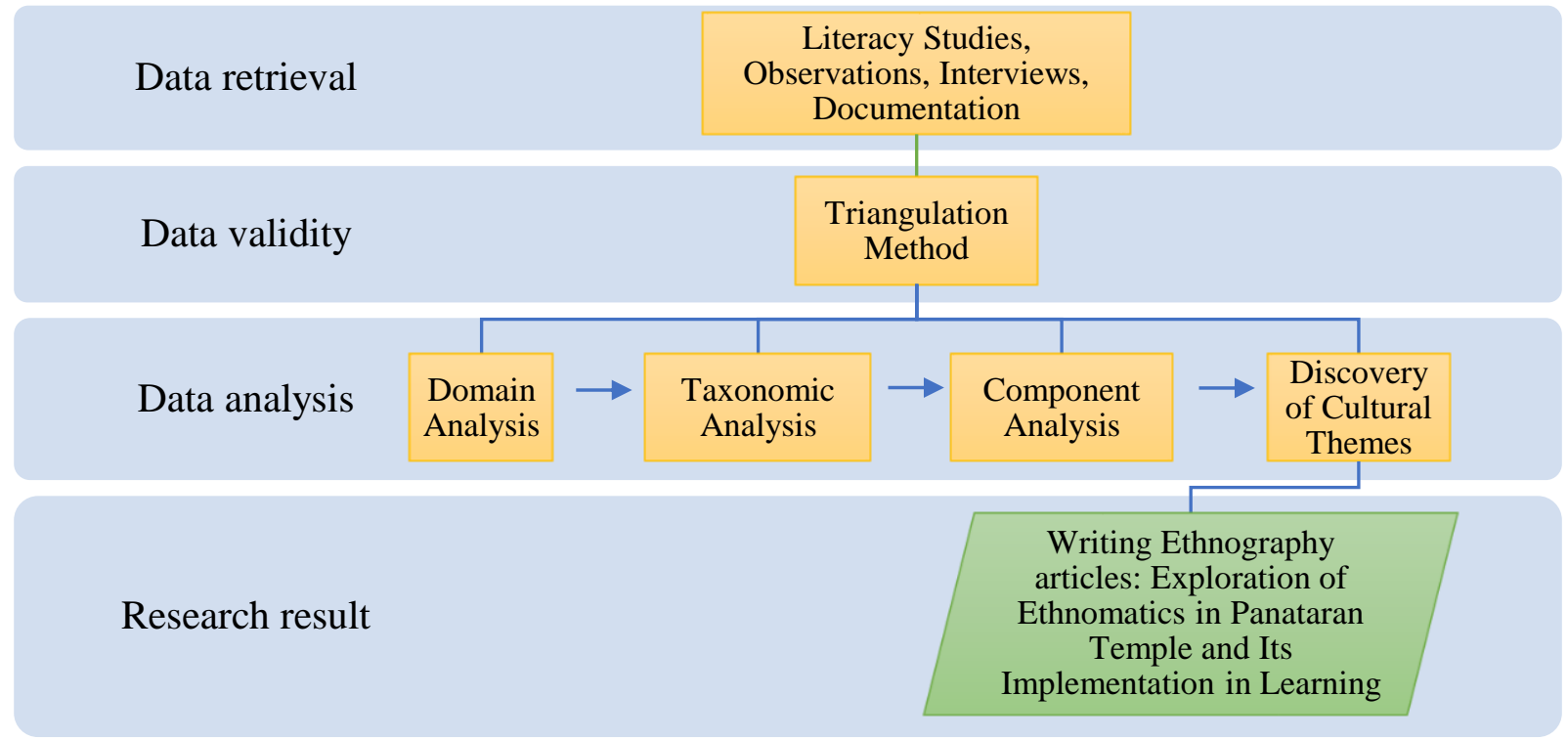

Figure 1. Research Flowchart

\section{RESULTS AND DISCUSSION}

From the data that has been obtained, the ethnomatematics contained in Panataran temple are:

\subsection{Bale Agung and Pendhopo Teras}

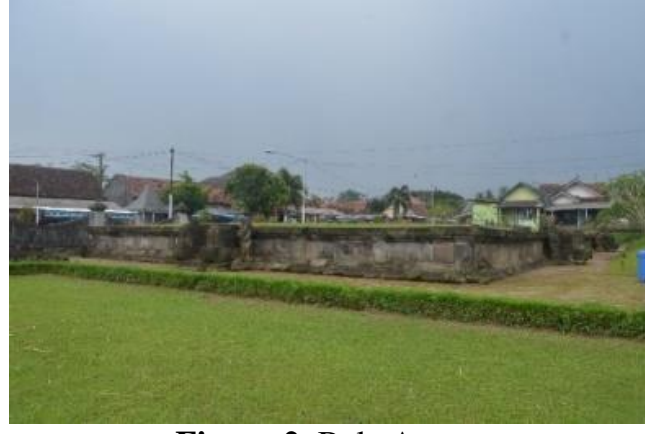

Figure 2. Bale Agung

Side view photo

Source: Documentation of the Cultural Heritage Conservation Center

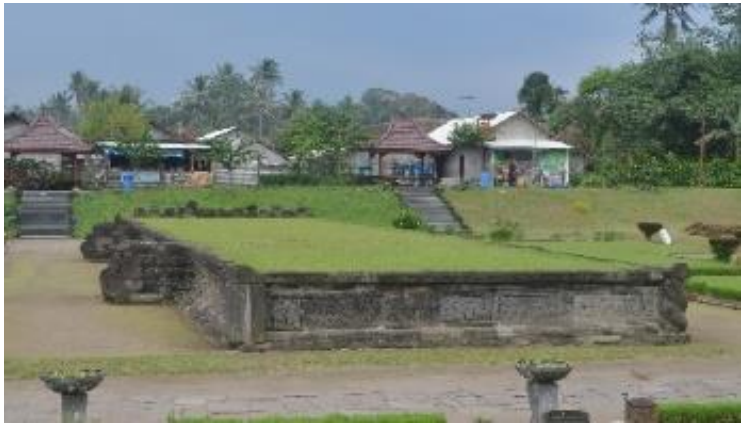

Figure 3. Pendhopo Teras

Front view photo (south)

Source: Documentation of the Cultural Heritage Conservation Center

Figures 2 and 3 are Bale Agung and Pendhopo Teras bulidings. Bale Agung and Pendhopo Teras buildings were made of stone which were the work of human. Bale Agung building has a function as a place of deliberation for religious leaders before doing religious ritual, meanwhile Pendhopo Teras serves as a place to put offerings for religious ritual. Pendhopo Teras also serves as a stage for performing traditional dance performances. Based on the seven elements of culture according to Mallinowski, it can be seen that Bale Agung and Pendhopo Teras buildings have cultural elements in the technology system, the religious system, and the arts. 


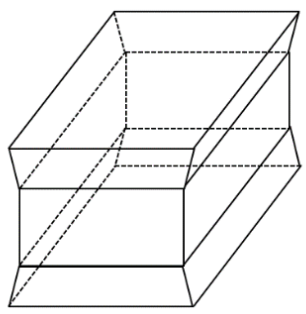

Figure 4. The Geometric Concept of the Bale Agung and Pendhopo Teras Buildings

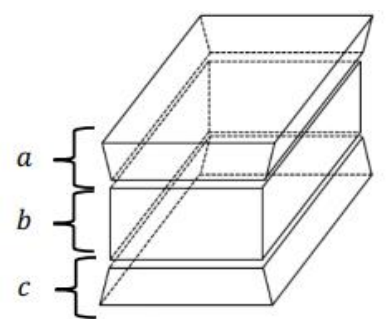

Figure 5. Three Prism Shapes

From Figure 4, it can be seen that the building is in the form of a polyhedron. Polyhedron is a space bounded by parts of the intersecting planes [20]. Figure 5 explains the separate parts of the polyhedron, there are three prism shapes in Figure 5 (shape a, shape $b$, and shape $c$ ). Prism is a polyhedron that has two parallel faces, while all the other sides are parallel to a line that intersects the two parallel sides [20]. Prisms can be classified according to two properties, the relation of the ribs to the base plane and the shape of the base plane. Based on the shape of the base plane, Shape a and c are the rectangular prism shapes. Based on the base plane, prism can be divided into triangular prism, rectangular prism, pentagon prism, and so on (an n-sided prism) [20]. Meanwhile, shape b is a cuboid shape. The beam, namely the beam is an upright parallepideum, the base of which is a rectangle. Thus, Bale Agung and Pendhopo Teras buildings have three buildings consisting of two rectangular prism shapes and one cuboid.

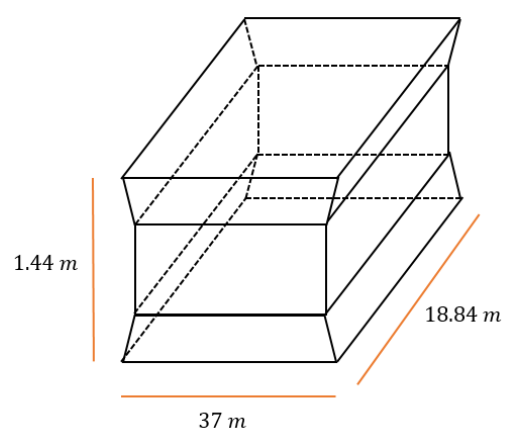

Figure 6. Bale Agung Building Size in Geometric Concept

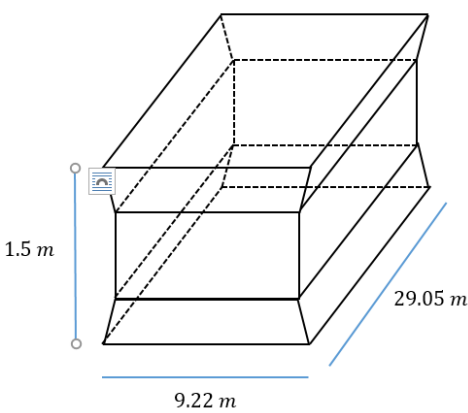

Figure 7. The Size of the Pendhopo Teras in Geometric Concept

Figures 6 and 7 show the size of the Bale Agung and Pendhopo Teras buildings which are illustrated through the mathematical concept of geometry. In learning at school, Bale Agung and Pendhopo Teras can be objects in geometry learning for grade VI according to Basic Competency point 3.7 "explaining a room shape which is a combination of several shapes, as well as surface area and volume", can also be an object of learning in class VIII, according to the Basic Competency point 3.9 "to distinguish and determine surface area and volume (cubes, cuboids, prisms and pyramids)" [21].

Budiarto \& Artiono said that one of the geometric problems based on basic geometry skills is visual skills [22]. Ethnomathematics-based learning can be a bridge to improve visual skills in learning geometry. Bale Agung and Pendhopo Teras are contextual objects that make it easier for students to recognize the shape of the cuboid and rectangular prism. Besides, these objects can be examples of buildings that have the shape of a cuboid and a rectangular prism. With contextual learning, various methods, and media to improve students' mathematical competence, teachers should make innovations in the learning process, one of which is by using variations in the mathematics learning process [23]. 
Learning variations can be in the form of culture-based mathematics learning (ethnomatematics). So, it is hoped that mathematics learning will be more meaningful and able to construct the learning experience of students.

\subsection{Angkatahun Temple}

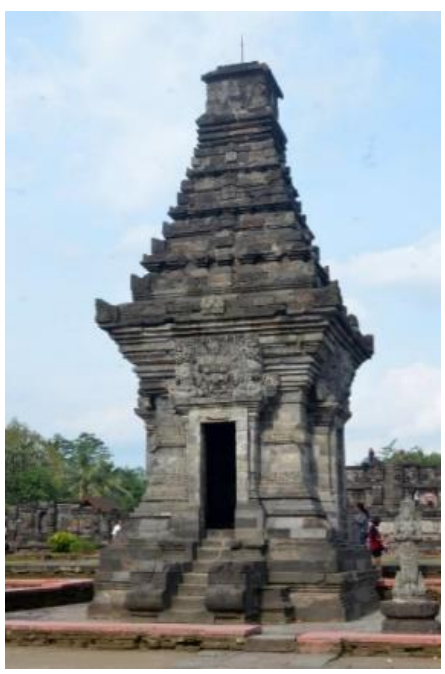

Figure 8. Angkatahun Temple Front view photo

Source: Documentation of the Cultural Heritage Conservation Center

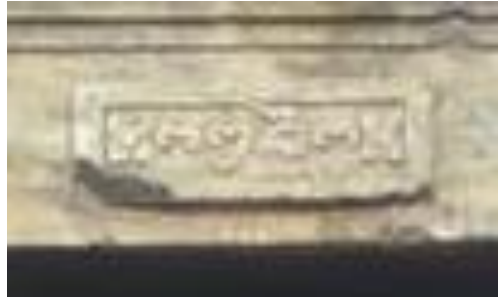

Figure 9. Year Numbers in Angkatahun Temple Front view photo

Source: Documentation of the Cultural Heritage Conservation Center

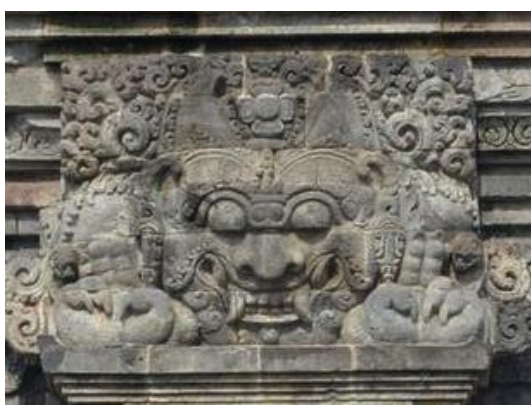

Figure 10. Relief of 'Kepala Kala' with Fingers Forming the symbol number 2 in the Angkatahun Temple

Source: Documentation of the Cultural Heritage Conservation Center

Figure 8 is the building of the Angkatahun Temple. Figure 9 is the Year Number engraved on the doorway of the Angkatahun Temple. This temple was called the Angkatahun because the building above the entrance door is engraved with the year 1291 Saka (1369 AD). Figure 10 is a relief of Kepala Kala (head of the time) with fingers forming the symbol number 2 in the Angkatahun Temple. All buildings and carvings in the year numbers are made of stone which is the work of humans. The Angkatahun temple serves as a place to worship the mountain god so that the mountain god does not get angry and create disaster, and as a proof of King Hayam Wuruk's love for the spirits of his ancestors. Based on the seven elements of culture according to Mallinowski, it can be seen that the Angkatahun Temple building has cultural elements in the technological system and the religious system. 


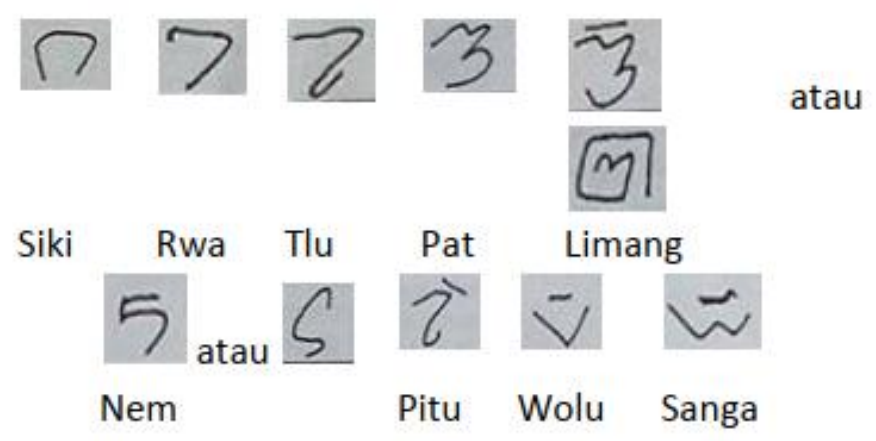

Figure 11. Numbers and Symbols of Numbers During the Majapahit Empire Source: Budiarto article (2016)

Figure 11 is numbers and number symbols during the Majapahit kingdom. Number is an abstract concept or idea that provides an overview of the total object, which in mathematics is used for counting and measuring [24], [25]. Number symbols are symbols used to represent a number. The number system knows no place and value, so it cannot develop [4]. Based on this number system, the number of years in the Angkatahun Temple is Siki Rwa Sanga Siki (1291 Saka). Numeralia are also known as number words [26]. The primary numeralia is the base number which is the source of the other numbers [26]. So that the Angkatahun (number of years) and Kepala Kala (the head of the time) of the Majapahit kingdom found in the Angkatahun Temple are symbols of numbers that become the main numeralia.

In mathematics learning in school, the relief of Angkatahun and the relief of Kepala Kala can be objects in the whole number topic for grade I according to the Basic Competency point 3.1 "explains the meaning of whole numbers up to 99 as members of a collection of objects" [21].

Learning at school with the objects of Angkatahun relief and Kepala Kala relief can be done by inviting students to take a trip to Panataran Temple. In addition to educating about the historical heritage of the Majapahit kingdom, teachers can also educate students for further understanding of the concept of numbers and symbols of numbers by explaining the meaning of whole numbers by counting. For grade I students, the head of the kala is suitable as a learning object for counting because the fingers formed on the relief of Kepala Kala are the symbol of number 2. Angkatahun relief is a Javanese number, in learning in school teachers can introduce Javanese numbers through learning media in the form of cards as has been done by Ekowati et al [27]. The card was made with two sides, the front side is a symbol of mathematical numbers in general $(1,2,3,4$, etc.) while the back side was a picture of the number of dancers or motifs of Batik Madura (Madurese batik motifs). In Ekowati et al research, they revealed that there were advantages in the application of ethnomatematics with the Madura batik media, traditional trenggal dances and Madurese special dances in learning, because they could deepen students' understanding of the topic of numbers [27]. This research also showed that mathematical activities that were usually considered abstract by students became more concrete by being associated with elements of local culture. 


\subsection{Naga (Dragon) Temple}

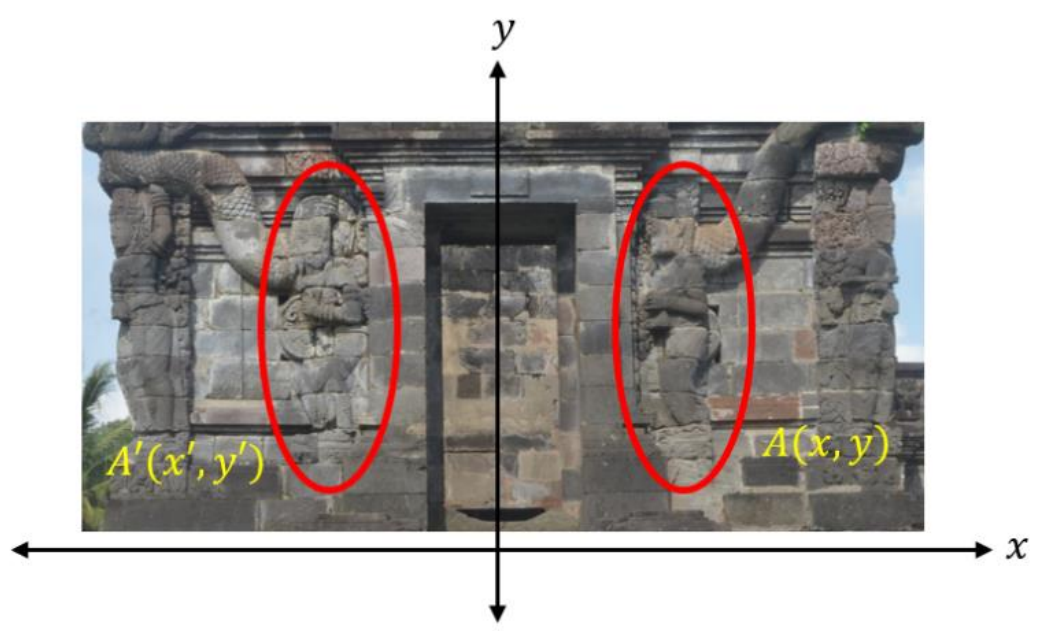

Figure 12. The Concept of Geometry Transformation on Nine Figures Relief Front view photo (north)

Source: Documentation of the Cultural Heritage Conservation Center

Figure 12 shows the reliefs of nine figures in Naga (Dragon) Temple who have the same shape. Naga Temple is made entirely of stone with the size of 4,83 $\mathrm{m} \times 6,57 \mathrm{~m} \times$ $4,70 \mathrm{~m}$. Thus, the reliefs engraved on the Dragon Temple were carved from stone. The Dragon Temple building is made of stone which is the work of humans. The Dragon Temple building serves as a place to store heirlooms for religious rituals. Based on the seven elements of culture according to Mallinowski, it can be seen that the Naga Temple building has cultural elements in the technological system and the religious system.

In the relief carving of nine figures, there is a mathematical concept of geometric transformation in the making. Gometric Transformation is the change of each coordinate point (fulcrum) into other coordinates on a plane with a certain rule [10]. For example, the transformation of $(T)$ to $P(x, y)$

$$
P(x, y) \rightarrow P^{\prime}\left(x^{\prime}, y^{\prime}\right)
$$

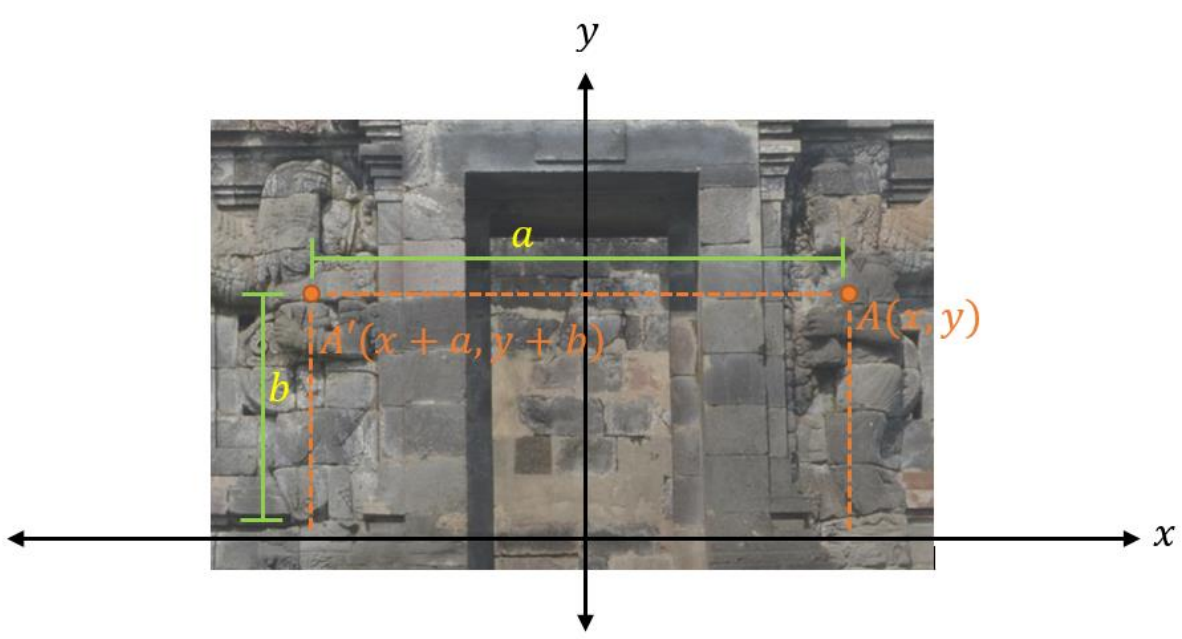

Figure 13. The Translation on Nine Figures Relief Front view photo (north)

Source: Documentation of the Cultural Heritage Conservation Center 
Equation (1) is a transformation of $(T)$ to $P(x, y)$ became $P^{\prime}\left(x^{\prime}, y^{\prime}\right)$. Figure 13 shows the reliefs of nine figures with the concept of geometric transformation, namely translation. Translation is a transformation that moves every point on a plane with a certain distance and direction [10]. The distance and direction in translation can be shown as a direct line.

$$
A(x, y) \stackrel{T=\left(\begin{array}{l}
a \\
b
\end{array}\right)}{\longrightarrow} A^{\prime}\left(x^{\prime}, y^{\prime}\right)=A^{\prime}(x+a, y+b)
$$

Equation (2) is an operation on translation. For example, $\overrightarrow{A B}$ or $\left(\begin{array}{l}a \\ b\end{array}\right)$, where " $a$ " shows the distance and direction which moves horizontally and " $b$ " shows the distance and direction which moves vertically. In every single translation, every shape does not change. The relief of nine figures is formed from the translation of one object. Figure 10 shows the translation process along a horizontal line to form a new object, so that it is like repeating the previous object with the same direction and shape. This shows that people in the Majapahit era used the concept of translational geometry transformation in making the reliefs of the nine figures in the Naga Temple. In learning, the relief of the nine figures in Naga Temple can be object in learning geometric transformation for grade IX according to Basic Competency point 3.5 "explaining geometric transformations (reflection, translation, rotation and dilation) associated with contextual problems" [21].

According to the research of Sudirman et al, Indramayu Batik motif artworks such as the Sawat Riwog, Setaman flowers and Obar Abir motifs, can be used as learning media on the topic of translational geometric transformation [28]. Students were asked to identify any motives that utilize the principle of translation. In addition, students also identified what geometric shapes were contained in batik motifs. So, the reliefs of the nine figures in the Dragon Temple can be an object of learning on the concept of translation. Fitriyah et al's research showed that after learning with discovery learning based teaching materials through ethnomathematic approach, students could remember the concept of geometric transformation easily through the Lampung batik patterns they often encounter [29].

\subsection{Induk (Main) Temple}

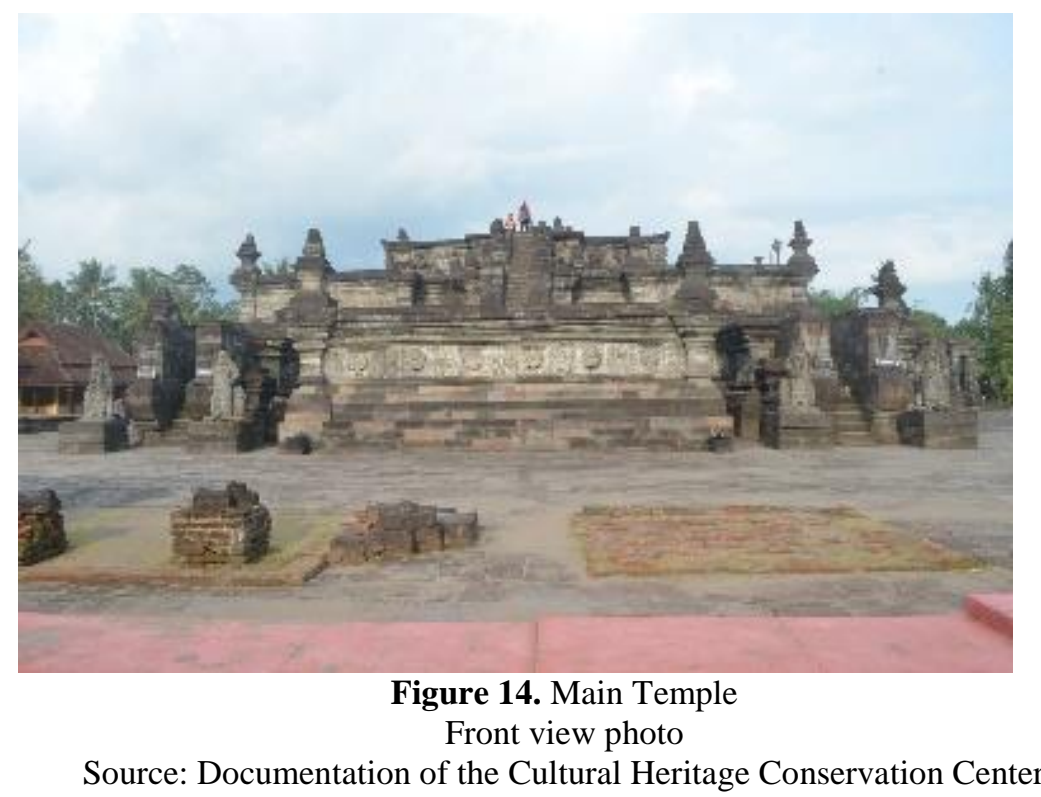

204 Indonesian Journa 1 of Science and Mathematics Education ( I J S M E ) 
Figure 14 is the main temple (Candi Induk) building. The main temple is made of stone and consists of three terraces with a total height of $7.19 \mathrm{~m}$. The first terrace has reliefs telling a story about Ramayana, the second terrace has reliefs telling about Kresnayana, and the third terrace has reliefs of Naga Wardhaya and Singa Naramurti. Folklore engraved on the three terraces becomes a means of communication for human in conveying thoughts, feelings, and concepts or ideas. The main temple building functions as a place for religious ceremonies. Based on the seven elements of culture according to Mallinowski, it can be seen that the main temple building has cultural elements in the technology system, language, and religious system.

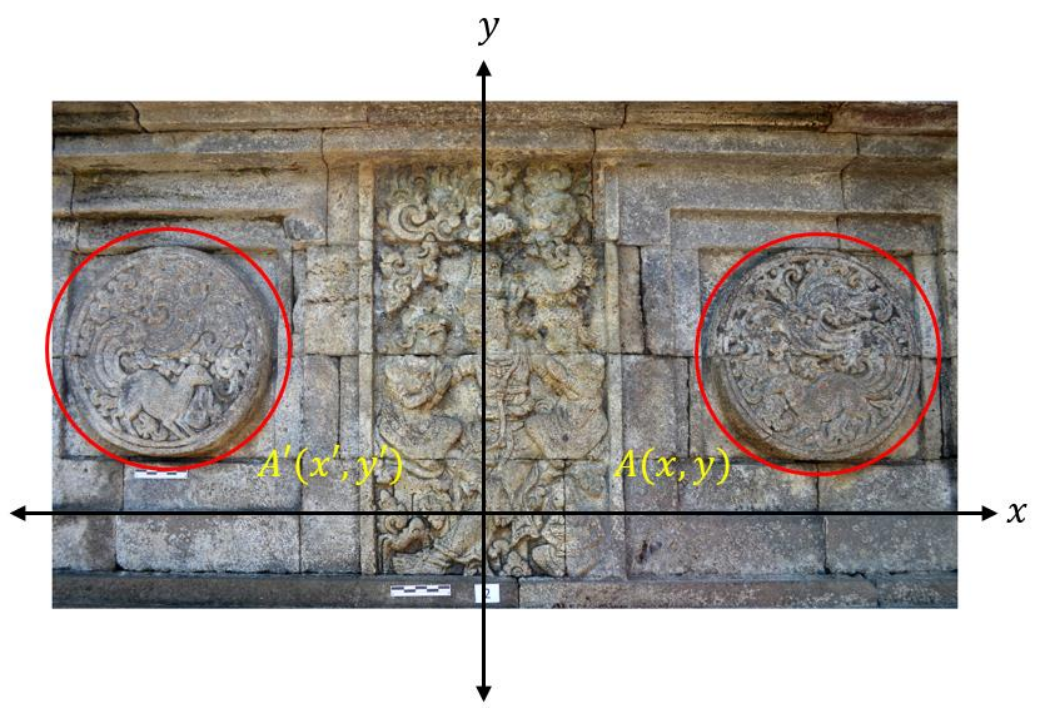

Figure 15. The Concept of Geometric Transformation in the Medallion Relief on the First Terrace of the Induk Temple (main temple)

Source: Documentation of the Cultural Heritage Conservation Center

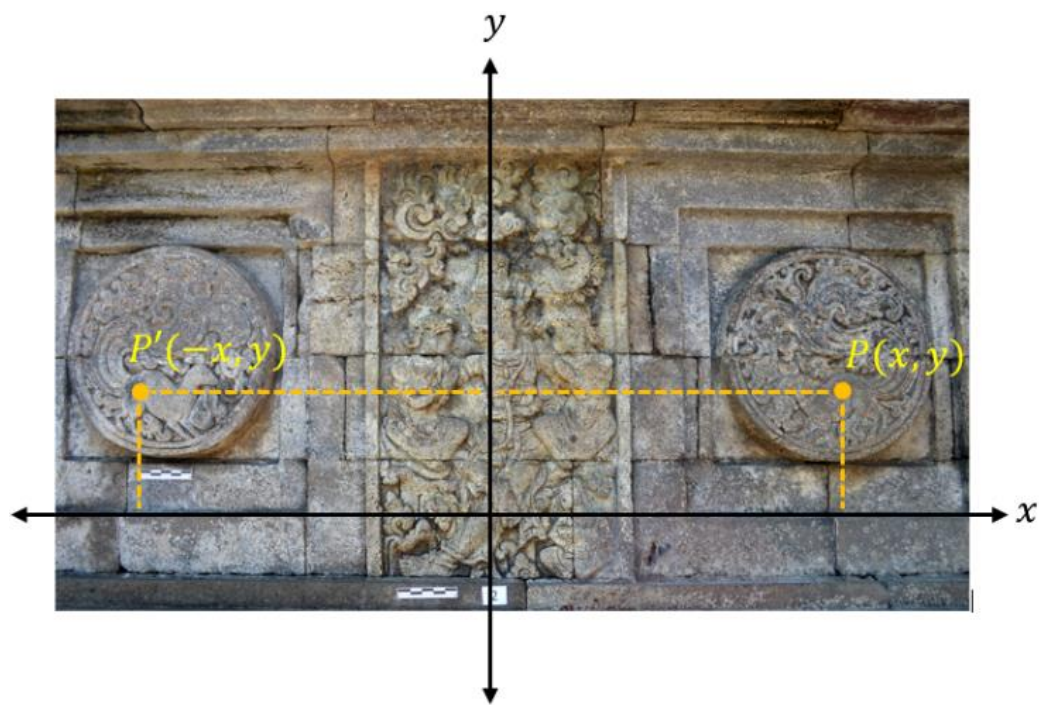

Figure 16. Reflection on the Medallion Relief on the First Terrace of the Induk Temple (Main Temple)

Source: Documents from the Cultural Heritage Conservation Center

At the main temple, there are reliefs that form a medallion motif as a barrier in story scenes in reliefs carved along the walls. Figures 15 and 16 show that the shape of the Relief Medallion at the Main Temple is similar. From this observation, it can be seen that ancient 
society used the concept of geometric transformation, namely reflection. Reflection is a transformation that moves each point of the plane by using the image mirroring of the point to be moved [10]. Reflection on $y$-axis (vertical), if the point on $P(x, y)$ is $P^{\prime}\left(x^{\prime}, y^{\prime}\right)$ so $P^{\prime}\left(x^{\prime}, y^{\prime}\right)=P^{\prime}(-x, y)$. The matrix form can be written as:

$$
\begin{gathered}
x^{\prime}=-x \\
y^{\prime}= \\
\left(\begin{array}{l}
x^{\prime} \\
y^{\prime}
\end{array}\right)=\left(\begin{array}{cc}
-1 & 0 \\
0 & 1
\end{array}\right)\left(\begin{array}{l}
x \\
y
\end{array}\right)
\end{gathered}
$$

Figures 15 and 16 show that people in ancient times used the concept of transformation in making Medalion reliefs at the main temple. In learning, the Medallion relief at the main temple can be an object in learning geometric transformation for grade IX in accordance with point 3.5 Basic Competency: "explaining geometric transformations (reflection, translation, rotation and dilation) associated with contextual problems" [21].

Yanti \& Haji's research reveals that the Bengkulu besurek batik cloth can be used as a learning medium and teaching aids in mathematics learning, especially in helping to understand the concepts of geometric transformation, and providing realistic and contextual outdoor learning [30]. In this case, the Medalion relief at the main temple can be a learning media. Furthermore, learning outside the classroom can be done by visiting the Panataran Temple. The teacher can make these objects as problem solving in learning.

\subsection{Prasasti Palah (Palah Incription)}

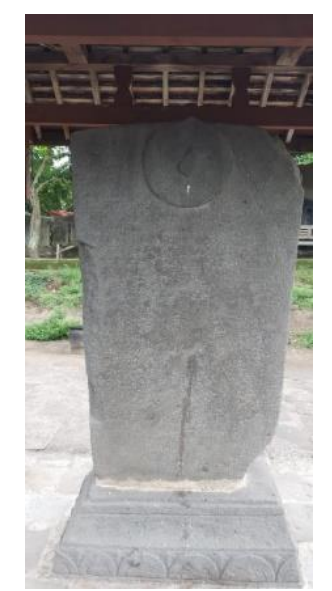

Figure 17. Palah Inscription

Front view photo

Source: Documentation of the Cultural Heritage Conservation Center

Figure 17 is the Palah inscription building. The Palah inscription contains the determination of Sima by King Srengga or Kertajaya which was intended as a means to maintain the continuity of worship for Paduka Bhatara in Palah. Sima was the Perdikan status of the Majapahit kingdom. Perdikan was a person who is exempt from paying taxes by the government. The sima was intended for four village heads so that they would properly guard and maintain the king's gift. The king's gift referred to in this case was free from the obligation to pay taxes and had authority over the government in the Candi Panataran area. Thus, it can be concluded that after the Palah inscription was made, the 
management of Panataran Temple was left to the four village heads, no longer directly managed by the kingdom.

Based on the seven elements of culture according to Mallinowski, cultural elements in the field of social organization explain that every community group life is regulated by customs and rules regarding various kinds of unity in the community where they must live and socialize [6], [7]. The Palah inscription contains customs and rules regarding the management of buildings in the Panataran Temple complex, so that the Palah inscription has elements of social organization culture.

The giving of sima to the four village heads at that time contained a mathematical concept, namely probability. Probability is a mathematical concept used to see the possibility of an event occurring [31]. The probability of an event can be defined as: If $n$ is the number of sample points in the sample space $S$ of an experiment, and $A$ is an event with the number of $n$ in the experiment, then the probability of $A$ is $P=\frac{n(A)}{n(S)}$.

In learning, the Palah inscription can be an object of mathematics learning for the topic of probability in class VIII according to the Basic Competition point 3.11 "explaining the empirical and theoretical chances of an event from an experiment". And in class XII learning, according to the Basic Competition point 3.4 about "describing and determining the probability of multiple events (the probability of mutually independent events, mutually exclusive, and conditional events) of a random experiment" [21].

Akbar et al explained that based on the analysis of students' error in working on mathematical problem solving problems on the topic of probability, the students' ability to understand problems was at a score of $48.75 \%$ (low), the ability to plan for solutions was $40 \%$ (low), the ability to solve problems $7.5 \%$ (very low), and the ability to evaluate $0 \%$ (very low) [32]. From this, it can be seen that the topic of probability is still categorized as a concept that is difficult for students to understand. The Palah inscription can be an object for learning mathematics on the topic of Probability. By visiting cultural practitioners and Panataran Temple, students will gain new experiences in learning. In addition to studying the cultural history of the Majapahit kingdom, students will also learn mathematical concepts of probability from their own observations. Learning outside the classroom can also be a variety of choices in learning, so that students do not feel bored in learning.

\section{CONCLUSION}

From the research results, it can be concluded that the Panataran Temple complex building has elements of culture and mathematical concepts. First, the Bale Agung and Pendhopo Teras buildings contain cultural elements in technological systems, religious systems, and arts, and the buildings apply mathematical concepts, namely Cuboid and Quadrilateral Prism. Second, the Angkatahun Temple building has cultural elements in technological systems and religious systems as well as mathematical concepts, namely Numbers and Numbers Symbols. Third, the Naga (Dragon) Temple building contains cultural elements in the technological system and the religious system, and contains the mathematical concept of translation. Fourth, in the main temple building there are cultural elements in the technology system, language, and religious systems, it also contains the mathematical concept of Reflection. Fifth, in the Palah inscription building, there are cultural elements in social organization and the mathematical concept of probability. Buildings in Panataran Temple can be objects of learning in schools for grade I and grade VI Elementary School, grade VIII and grade IX Junior High school, and class XII Senior High school. 


\section{REFERENCES}

[1] V. G. A. Peursen, Strategi Kebudayaan. Yogyakarta: Kanisius, 1998.

[2] N. K. Ratna, Metode Penelitian Kajian Budaya Dan Ilmu-Ilmu Sosial Humoria Pada Umumnya. Yogyakarta: Pustaka Pelajar, 2010.

[3] A. Wahyuni, A. Aji, W. Tias, and B. Sani, "Peran Etnomatematika dalam Membangun Karakter Bangsa:," in Prosiding Seminar Nasional Matematika dan Pendidikan Matematika FMIPA UNY, 2013.

[4] M. T. Budiarto, "Etno-Matematika: Sebagai Batu Pijakan Untuk Pembelajaran Matematika," in Prosiding Seminar Nasional Pendidikan Matematika, 2016.

[5] KBBI, "KBBI Daring," Kementrian Pendidikan dan Kebudayaan. 2020, [Online]. Available: https://kbbi.kemendikbud.go.id.

[6] N. Anshory, Strategi Kebudayaan: Titik Balik Kebudayaan Nasional. Malang: UB Press, 2013.

[7] S. Kusumawati, "LEKSIKON BUDAYA DALAM UNGKAPAN PERIBAHASA SUNDA (Kajian Antropolinguistik)," Lokabasa, vol. 7, no. 1, p. 87, 2016, doi: 10.17509/jlb.v7i1.3421.

[8] D. Muhtadi, Sukirwan, Warsito, and R. C. I. Prahmana, "Sundanese ethnomathematics: Mathematical activities in estimating, measuring, and making patterns," J. Math. Educ., vol. 8, pp. 185-198, 2017, doi: 10.22342/jme.8.2.4055.185-198.

[9] I. Risdiyanti and R. C. Indra Prahmana, "Ethnomathematics: Exploration in Javanese culture," J. Phys. Conf. Ser., vol. 943, p. 012032, Dec. 2017, doi: 10.1088/1742-6596/943/1/012032.

[10] C. Ditasona, "Ethnomathematics Exploration of the Toba Community: Elements of Geometry Transformation Contained in Gorga (Ornament on Bataks House)," in IOP Conference Series: Materials Science and Engineering, 2018, pp. 1-6, doi: 10.1088/1757-899X/335/1/012042.

[11] A. Arisetyawan, D. Suryadi, T. Herman, and C. Rahmat, "Study of Ethnomathematics : A lesson from the Baduy Culture," Int. J. Educ. Res., vol. 2, pp. 681-688, 2014.

[12] Zaenuri and N. Dwidayati, "Exploring ethnomathematics in Central Java," in Journal of Physics: Conference Series, 2018, pp. 1-6, doi: 10.1088/17426596/983/1/012108.

[13] U. D'Ambrosio, "Ethnomathematics and its Place in the History and Pedagogy of Mathematics.," Learn. Math. - An Int. J. Math. Educ., vol. 5, pp. 44-48, 1985.

[14] M. T. Budiarto, R. Artiono, and R. Setianingsih, "Ethnomathematics: Formal Mathematics Milestones for Primary Education," in Journal of Physics: Conference Series, 2019, pp. 1-6, doi: 10.1088/1742-6596/1387/1/012139.

[15] Abbas, Soekarsono, E. Triharyantoro, Sunarti, and H. Herayuni, Peninggalan Sejarah dan Kepurbakalaan di Jawa Timur. Surabaya: Dinas Pendidikan dan Kebudayaan Propinsi Jawa Timur, 2001.

[16] Ngadiono, W. S. D. Mambo, E. Triharyantoro, H. Herayuni, and E. Widodo, Peninggalan Sejarah dan Kepurbakalaan Candi Panataran. Surabaya: Dinas Pendidikan dan Kebudayaan Porpinsi Jawa Timur, 2003.

[17] S. W. Wardhono, Memperkenalkan Komplek Percandian Panataran di Blitar. Mojokerto: KPN Purbakala, 1995.

[18] J. P. Spradley, Metode Etnografi (terjemahan). Yogyakarta: Tiara Wacana, 2006.

[19] B. S. Bachri, "Meyakinkan Validitas Data Melalui Triangulasi Pada Penelitian Kualitatif," J. Teknol. Pendidik., vol. 10, pp. 46-62, 2010.

208 Indonesian Journal of Science and Mathematics Education 
[20] Isrok'atun, Pendidikan Matematika II, Isrok'atun. Sumedang: UPI Sumedang Press, 2016.

[21] Kemendikbud, "Permendikbud 37 tahun 2018," Kementerian Pendidikan dan Kebudayaan. Jakarta, 2018.

[22] M. T. Budiarto and R. Artiono, "Geometri dan Permasalahan Dalam Pembelajarannya (Suatu Penelitian Meta Analisis)," JUMADIKA (Jurnal Magister Pendidik. Mat., vol. 1, pp. 9-18, 2019.

[23] Trisnawati, "Pembelajaran Kontekstual ( Contextual Teaching and Learning ) Pada Bangun Ruang Sisi Datar," pp. 146-155, 2018.

[24] R. Salam, Nurfaizah, L. S, Pattabundu, and W. K. S. Achmad, "Sumber Belajar Penunjang PLPG 2016 Mata Pelajaran/Paket Keahlian Guru Kelas SD," Kementeri. Pendidik. DAN Kebud. DIREKTORAT JENDERAL GURU DAN TENAGA KEPENDIDIKAN 2016, 2016.

[25] N. B. R. Sujono, "Pengaruh Terhadap Peningkatan Perkembangan Mengenal Lambang Bilangan Anak Kelompok B di TK Tunas Melati II Kecamatan Natar Kabupaten Lampung Selatan," Fak. Kegur. DAN ILMU Pendidik. Univ. LAMPUNG, vol. 13, no. 3, pp. 1576-1580, 2017.

[26] P. M. Sasti, Istilah Satuan Ukuran dalam Bahasa Jawa. Semarang: Balai Bahasa Jawa Tengah Kementrian Pendidikan dan Kebudayaan, 2017.

[27] D. W. Ekowatii, D. I. Kusumaningtyas, and N. Sulistyani, "Ethnomathematica Dalam Pembelajaran Matematika (Pembelajaran Bilangan Dengan Media Batik Madura, Tari Khas Trenggal Dan Tari Khas Madura)," J. Pemikir. dan Pengemb. Sekol. Dasar, vol. 5, no. 2, p. 716, 2017, doi: 10.22219/jp2sd.vol5.no2.716-721.

[28] Sudirman, Rosyadi, and W. D. Lestari, "Penggunaan etnomatematika pada karya seni batik Indramayu dalam pembelajaran geometri transformasi," Pedagogy, vol. 2, no. 1, pp. 74-85, 2017.

[29] D. N. Fitriyah, H. Santoso, and N. Suryadinata, "Bahan Ajar Transformasi Geometri Berbasis Discovery Learning melalui Pendekatan Etnomatematika," J. Elem., vol. 4, no. 2, p. 145, 2018, doi: 10.29408/jel.v4i2.705.

[30] D. Yanti and S. Haji, "Studi Tentang Konsep-Konsep Transformasi Geometri Pada Kain Besurek Bengkulu," JNPM (Jurnal Nas. Pendidik. Mat., vol. 3, no. 2, p. 265 , 2019, doi: 10.33603/jnpm.v3i2.1744.

[31] A. Fauzi and U. Lu'luilmaknun, "Etnomatematika pada Permainan Dengklaq sebagai Media Pembelajaran Matematika," AKSIOMA J. Progr. Stud. Pendidik. Mat., vol. 8, no. 3, p. 408, Dec. 2019, doi: 10.24127/ajpm.v8i3.2303.

[32] P. Akbar, A. Hamid, M. Bernard, and A. I. Sugandi, "Analisis Kemampuan Pemecahan Masalah Dan Disposisi Matematik Siswa Kelas Xi Sma Putra Juang Dalam Materi Peluang," J. Cendekia J. Pendidik. Mat., vol. 2, no. 1, pp. 144-153, 2017, doi: 10.31004/cendekia.v2i1.62. 